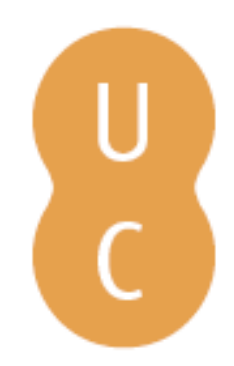

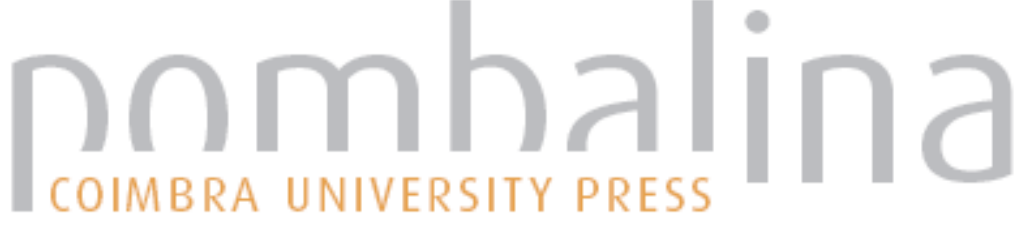

\section{Cidadania, nacionalismo e propaganda política}

\author{
Autor(es): $\quad$ Paulo, Heloisa; Torgal, Luís Reis
}

Publicado por: Imprensa da Universidade de Coimbra

URL

persistente: URI:http://hdl.handle.net/10316.2/36649

DOI: $\quad$ DOI:http://dx.doi.org/10.14195/978-989-26-0873-0_10

Accessed : $\quad$ 26-Apr-2023 15:47:27

A navegação consulta e descarregamento dos títulos inseridos nas Bibliotecas Digitais UC Digitalis, UC Pombalina e UC Impactum, pressupõem a aceitação plena e sem reservas dos Termos e Condições de Uso destas Bibliotecas Digitais, disponíveis em https://digitalis.uc.pt/pt-pt/termos.

Conforme exposto nos referidos Termos e Condições de Uso, o descarregamento de títulos de acesso restrito requer uma licença válida de autorização devendo o utilizador aceder ao(s) documento(s) a partir de um endereço de IP da instituição detentora da supramencionada licença.

Ao utilizador é apenas permitido o descarregamento para uso pessoal, pelo que o emprego do(s) título(s) descarregado(s) para outro fim, designadamente comercial, carece de autorização do respetivo autor ou editor da obra.

Na medida em que todas as obras da UC Digitalis se encontram protegidas pelo Código do Direito de Autor e Direitos Conexos e demais legislação aplicável, toda a cópia, parcial ou total, deste documento, nos casos em que é legalmente admitida, deverá conter ou fazer-se acompanhar por este aviso.

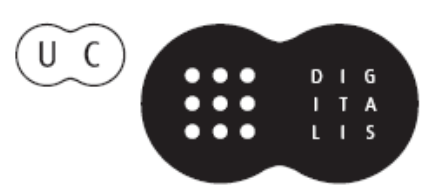


www.uc.pt/ imprensa_uc CONTACTO imprensa@uc.pt VENDAS ONLINE http://livrariadaimprensa.uc.pt JANEIRO 2015
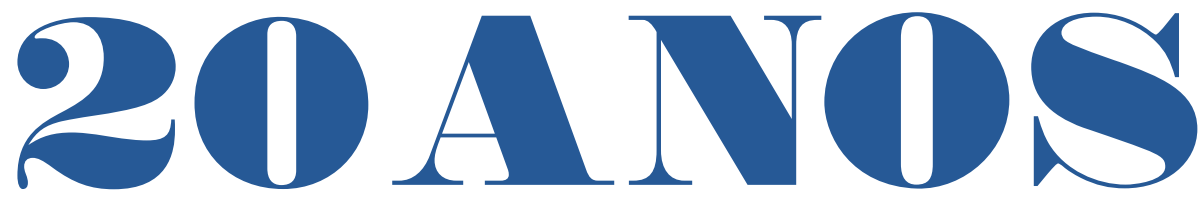

\section{DE JORNALISMO CONTRA A INDIFERENÇA}

TEXTOS DE

Marc Lits, Adriano Duarte Rodrigues, Tito Cardoso e Cunha, José Augusto Mourão, Alberto Pena Rodríguez, Maria Augusta Babo, Daniel Cronu, João Pissarra Esteves, Gilles Gauthier, Heloísa Paulo e Luís Reis Torgal, Alfredo Barroso, António Fidalgo, Nöel Nel, João de Almeida Santos, Juan Luis Cebrián, António Dias Figueiredo, Marina Themudo, Jorge Sampaio, Nelson Traquina, Mário Soares
( livro que agora se apresenta, nasce de dois desígnios fundamentais: por um lado, celebrar duas décadas de ensino do Jornalismo na Universidade de Coimbra e, por outro, partilhar com um público mais alargado um conjunto de reflexões sobre os media, o jornalismo, a comunicação e o espaço público.

Se o ensino superior do Jornalismo em Portugal, relativamente tardio em relação ao resto da Europa, deu os seus primeiros passos no fim dos anos 70 do século passado, ele aparece apenas duas décadas depois na academia coimbrã. Contudo, esta foi, no contexto nacional, a primeira licenciatura em Jornalismo, distinguindo-se, quer em título, quer em objetivos, das licenciaturas então existentes no país. A criação de uma Licenciatura em Jornalismo na Universidade de Coimbra, em 1993-1994, foi, por si, um acontecimento. Com efeito foi necessário que reitor, professores e jornalistas ousassem atualizar a oferta curricular da Faculdade de Letras, oferecendo um curso há muito desejado pela sociedade e pelo mercado, embora desconsiderado por alguns setores da academia. Correndo o risco de omitir alguém, a quem antecipadamente pedimos desculpa, não podemos deixar de recordar os esforços dos jornalistas João Mesquita, João Fonseca, em representação
Todas as gerações, sem dúvida, se julgan para refazer o mundo. A minha sabe, nc que não poderá refazê-lo. A sua tarefa é tc

Consiste em impedir que se desfaça, $p$ unicamente das suas negações A. Camus, Discursos da Suécia (1957)

do Sindicato dos Jornalistas, e de Jorge Castilho, a quem mais tarde se viria associar o nome de Mário Martins, bem como o do então Reitor da Universidade de Coimbra Rui Alarcão, e dos professores João Roque e Luís Reis Torgal. Entre 1993 e 1996, a Licenciatura em Jornalismo funcionou com um Secretariado, que teve um papel executivo e científico nos primeiros tempos do curso na FLUC. Presidido pelo Presidente do Conselho Científico Ludwig Scheidl, este 


\section{Cidadania, Nacionalismo e Propaganda Política}

Heloisa Paulo e Luís Reis Torgal

CEIS20 - UC

\section{As imagens do autoritarismo: a repressão em nome dos direitos dos cidadãos.}

Nos meios de comunicação da atualidade a evocação dos regimes fascistas é baseada em metáforas de força e repressão que, acompanhadas de imagens, relatos e testemunhos, tendem a reforçar a feição autoritária destes regimes. E, se, por um lado, as fontes documentais, sobretudo os relatos orais, deixam transparecer o clima de opressão então vivido, as imagens retiradas dos filmes documentários de época, vistas isoladamente, podem induzir numa leitura mais amena da prática quotidiana destes mesmos Estados. Na verdade, o fascismo, tais como as demais formas de autoritarismo, uma vez no poder, não assume a violência como ponto de referência ${ }^{1}$. A visão de uma sociedade ordenada, ritualizada e voltada para um único ideal está presente na propaganda e nos textos oficiais que "legalizam" a existência dos poderes constituídos. Esta “ordem” encontra-se centrada em duas ideias amplamente difundidas e incorporadas como realidades pelos sistemas liberais: a cidadania e a nacionalidade.

Assim sendo, para os regimes autoritários, sobretudo para os de cunho fascista, as questões da nacionalidade e da cidadania encontram-se vinculadas ao Estado e são determinadas pelas directrizes políticas impostas pelos poderes estatais, já que o próprio Estado se apresenta como o defensor máximo de uma determinada ideia de "Nação". O exercício da cidadania e a "defesa" do sentimento nacional são vistos como partes de uma mesma postura que, por sua vez, é determinada pela aceitação das normas ditadas pelo Estado. Este tipo de argumentação, juntamente com um apelo constante ao combate das injustiças sociais e à necessidade de mudança, contribuem para

\footnotetext{
${ }^{1}$ É interessante notar que o fascismo quando alcança o poder tende a substituir a sua simbologia "oficial". Em termos da propaganda destinada à juventude, por exemplo, a imagem revolucionária e belicosa dos jovens fascistas desaparece para dar lugar ao "balila" bem comportado e sempre disposto a obedecer aos comandos dos seus superiores. Sobre o tema ver: Laura Malvano. "O mito da juventude transmitido pela imagem: o fascismo italiano”, in: G. Levi e C. Schmitt(org.). História dos Jovens. São Paulo, Companhia das Letras, 1996, v. II.
} 
a promoção do consenso em torno das propostas canalizadas pelos mais diversos aparelhos de propaganda destes regimes. A imagem da "ordem" extrapola os textos jurídicos, sendo "corporizada" por atores especiais, pessoas comuns que participam do quotidiano e das ritualizações promovidas por estes Estados.

Na verdade, participar de um cerimonial, ser o foco de uma imagem ao serviço do regime significava para muitos o exercício de um tipo de cidadania. Não sendo "donos" da sua imagem, não reclamando da sua manipulação, os "cidadãos nacionalistas" acreditavam que incorporavam um retrato maior do que o seu próprio. Anulados como indivíduos, sentiam-se parte de uma visão mística, ou seja, de uma Nação abstrata, mas soberana, para a qual emprestavam os seus rostos e hipotecavam o seu apoio².

As imagens destes rituais e cerimónias registadas nos documentários cinematográficos, fotografias e cartazes de propaganda confirmam esta perspectiva e "retificam" a ideia da "ordem" e do assentimento geral em torno destes regimes. Qualquer manifestação contrária a esta representação da sociedade e ao papel desempenhado pelos respectivos Estados é considerada uma ameaça que deve ser reprimida como um símbolo da "desordem" e do "não-nacionalismo"3. Desta forma, não há contradição entre a permanência em vigor dos antigos textos constitucionais, defensores das liberdades individuais, e a vigência de novas legislações, de cunho coercivo, que promovem a repressão aos opositores destes regimes.

Neste quadro, sem se assumirem como opressores, estes Estados esforçamse por "banir" as oposições, contrárias aos "ideais nacionalistas", e "limpar" do quotidiano as suas desgraças comuns, já que perturbam a visão idílica que edificam da sua própria atuação e da realidade. Os veículos de comunicação são transformados, gradativamente, em agentes fundamentais de uma informação que, deixando de lado a seriedade jornalística, passa a atuar como propaganda ideológica. As notícias veiculadas pelos meios de comunicação traduzem a imagem de uma vida perfeita, onde não existem os factos que, anteriormente, demarcavam o lado "negro" da sociedade, como a criminalidade ou a revolta. Aos "verdadeiros cidadãos" cabe, por consequência, o não questionamento das "verdades" transmitidas.

\footnotetext{
${ }^{2}$ Sobre o tema, ver, entre outros, George Mosse. L'uomo e le masse nelle ideologie nazionaliste. Roma-Bari, Laterza, 1988; George Mosse. La nazionalizzazione delle masse. Bolonha, Il Mulino, 1993, e Emilio Gentile. Il culto del littorio, Roma-Bari, Laterza, 1994. 3 Sobre o tema ver: Emilio Gentile. "La nazione del fascismo. Alle origini della crisi dello Stato nazionale in Italia”. Storia Contemporanea, Anno XXVI, dezembro, 1993.
} 
Assim sendo, nos anos trinta, quando os fascismos clássicos estão consolidados no poder, países como a Itália e a Alemanha não deixam de manter a circulação dos periódicos, ainda que uma grande maioria deles tenha deixado de circular livremente devido ao seu não "enquadramento" ideológico. Os jornais existentes ficam subordinados a uma legislação especial, censora e repressiva, mas que apela para a defesa dos "interesses nacionais". Em Itália, por exemplo, a partir de 1924 é instituído um decreto sobre a Imprensa que deu aos presidentes das câmaras de cada uma das províncias italianas o poder de confiscarem jornais que publicassem noticiário contrário à ideologia vigente e aos interesses do regime. Em 1926, com a promulgação das "Leis de Defesa do Estado", conhecidas por "Leis Fascistíssimas”, nenhum jornal consegue circular sem possuir uma licença própria fornecida pelo Estado e Federação da Imprensa Italiana, até então um poderoso organismo que congregava os principais diretores de periódicos da Itália, passa para o controlo do Sindicato Nacional Fascista de Periódicos. Em 1933 este processo de controlo é consolidado com a criação do Sub-Secretariado para a Imprensa e Propaganda, um primeiro ensaio para o controlo de todos os meios de comunicação. Quatro anos mais tarde, temos a instituição do Ministério de Cultura Popular, que passa a partir de junho do mesmo ano a controlar não só a imprensa, mas a rádio, o teatro, o cinema e todas as manifestações culturais. A censura, que até então ficara a cargo da única agência telegráfica distribuidora do noticiário para todo o país, a Agenzia Stefani, passa, de igual forma, para o Miniculpop, como passa a ser conhecido o Ministério ${ }^{5}$.

O controlo sobre a Imprensa é intensificado e ao entrarmos na década de trinta não existe mais imprensa assumidamente de oposição na Itália. As informações sobre crimes, atos da oposição, regimes estrangeiros contrários ao italiano, posturas religiosas contrárias à Igreja de Roma ${ }^{6}$ ou notícias sobre atentados sexuais, ou homossexualismo são alvos de corte sumário. Entre

\footnotetext{
${ }_{4}^{4}$ Conjunto de leis promulgadas pelo governo fascista em dezembro de 1926, que acentuam a fascização da sociedade italiana.

5 Sobre o tema ver, entre outros: Edward Tannenbaum. La experiencia fascista. Sociedade y cultura en Italia (1922-1945). Madrid, Alianza Universidad, 1975, e Philip V. Cannistraro. La fabbrica del consenso. Fascismo e Mass Media. Bari, Laterza, 1974 .

${ }^{6}$ Notar que em Itália, ao contrário do que ocorreu na Alemanha com boa parte das Igrejas Católica e Protestante, foi de suma importância para a divulgação do regime o apoio dos padres, nomeadamente após os Acordos de Latrão com o Vaticano, em 1929, e a Encíclica Quadragesimo Anno, de 1931, na qual o Papa Pio XI reconheceu o valor do Estado Corporativo.
} 
1937 e 1938 são expedidas mais de 4.000 ordens de censura e postas em prática 400 sanções contra jornais que não haviam obedecido a estas ordens ${ }^{7}$. A regra é seguir atentamente as normas de controlo, expressas de uma forma precisa numa das recomendações feitas, acerca de um dos discursos de Mussolini, pelo serviço de censura aos jornais: “'Il discorso del Duce può essere

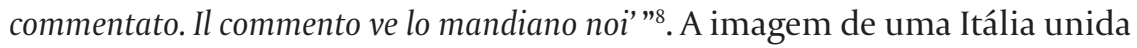
em torno do fascismo e do seu líder, apesar das contestações internas, tende a prevalecer graças à repressão, não deixando espaço para outras visões acerca da realidade fascista.

De igual forma, na Alemanha, em 1933, a criação do órgão oficial de propaganda do Terceiro Reich, o Ministério da Propaganda, chefiado por Goebbels, possui entre as suas directrizes fundamentais o controlo da informação e o fim de qualquer forma de expressão que se pudesse opor à veiculada pelo regime. É importante frisar, porém, que, durante toda a vigência do nazismo, a Constituição de Weimar, considerada um avanço em termos de defesa dos direitos individuais, nunca é revogada, apoiando-se Hitler para o exercício do seu poder no artigo 48 do texto constitucional alemão de 1919, que conferia a possibilidade de uma gestão extraparlamentar ao chanceler da Alemanha. Legalmente, portanto, dentro dos limites impostos pelo novo conceito de "cidadania”, os membros da sociedade alemã continuam a gozar das antigas liberdades individuais propagadas pelo texto de Weimar, tais como a de associação ${ }^{9}$.

O apelo à defesa do nacionalismo alemão, leva, no entanto, à superação dos demais artigos constitucionais, transformando a censura numa prática corrente. Para os periódicos são criadas as Sprachregelungen (instruções de linguagem), que nada mais são do que boletins oficiais diários de informações enviados para os jornais pelo Ministério de Propaganda. Os editores, após tomarem conhecimento do seu conteúdo e assinarem um termo de recebimento e compromisso de divulgação, têm ordens de destruírem as "Instruções" recebidas ${ }^{10}$. Os jornais da oposição são proibidos e a imprensa,

\footnotetext{
${ }^{7}$ Ver, entre outros, Edward Tannenbaum. “Cultura Popular e Propaganda”, in op. cit.

${ }^{8}$ Citado por Mario Isnenghi. "Per la storia delle istituzioni culturali fasciste", in: Intellectuali Militante e Intellectuali funzionari. Apunti sulla cultura. Torino, Einaudi, 1979. p. 55 .

${ }^{9}$ Sobre o tema ver, entre outros, Enzo Collotti. Hitler e il Nazismo. Firenze, Giunti, 1994, p. 15 e seguintes.

${ }^{10}$ Algumas destas Instruções trazem ordens explícitas como a proibição de notícias sobre Thomas Mann e outros opositores do regime, figuras como Charles Chaplin ou informações sobre a presença de potássio na ração dos animais de abate.
} 
seguindo as ordens do Ministério, torna-se monótona e repetitiva. Em 1938 o Partido controla direta ou indiretamente um terço dos periódicos em circulação no país ${ }^{11}$. Dos 4.500 periódicos existentes em 1933, restam apenas 1.000 em 1939. Nesse ano já não se pode notar quaisquer diferenciações entre os noticiários dos jornais alemães pois todos eles se limitam a reproduzir as informações fornecidas pelo Ministério de Propaganda. Os principais jornais são aqueles vinculados ao Partido, como o Völkischer Beobachter, fundado em 1920, cujo texto escrito é praticamente inexistente, predominando o apelo visual, tão característico da propaganda oficial. Sendo leitura obrigatória para os membros do partido, a sua tiragem aumenta consideravelmente no decorrer dos anos trinta. Outros casos são o Die Brennessel, de cunho humorístico, editado em Munique, onde colaboram desenhistas famosos como Josef Plank que, utilizando o pseudónimo de Seppla, assina as caricaturas mais mordazes de ataque aos ingleses e soviéticos. Nos demais meios de comunicação a ação censória é exercida, de igual forma, por câmaras ou conselhos encarregados do controlo de cada um destes meios. O cinema, pela Lei do Cinema do Reich, fica submetido a dois tipos de atuação: quanto aos filmes alemães é obrigatório o exame prévio do guião, incluindo-se neste os cenários e possíveis locais de rodagem de cenas, e o registo dos artistas que participariam nas filmagens, pela Câmara de Cultura do Reich ${ }^{12}$ (Reichskulturkammer); quanto aos filmes estrangeiros, o corte ou a proibição das películas contrárias ao ideal nazi ${ }^{13}$. Na Rádio, temos o fim da autonomia das pequenas rádios locais e a concentração de todas as emissões a partir do Befehszentrale, o Centro de Emissão de Ordens, do Ministério de Goebbels. O controlo dos demais meios de expressão artística é diretamente exercido por este, com a vigilância cerrada da Câmara de Cultura do Reich, através, inclusivamente, da elaboração de "listas negras" que colocam na ilegalidade do regime obras e autores que lhe são contrários ${ }^{14}$.

\footnotetext{
"Sobre o tema ver, entre outros, Oron J. Hale. The Captive Press in the Third Reich. Princeton, Priceton University Press, 1964.

${ }^{12}$ A partir de setembro de 1933 todo o artista que queira exercer atividade é obrigado a submeter-se à aprovação da Câmara de Cultura, sem a qual não obtém o registo para o exercício legal da profissão. Sobre o tema ver, entre outros: Hildegard Brenner. La politica culturale del Nazismo. Bari, Laterza, 1965, ou ainda, David Welch. The Third Reich. Politics and Propaganda. London, Routledge, 1995.

${ }^{13}$ Do filme francês Nana, baseado no romance de Zola, são cortadas as cenas de um soldado com uma prostituta, por serem contrárias à imagem do jovem soldado alemão de "bons costumes", voltado para a camaradagem e a reprodução da raça ariana.

${ }^{14} \mathrm{O}$ controlo e a condenação de toda e qualquer expressão artística contrária à estética
} 
Em Espanha, ainda em plena guerra civil, na zona nacionalista ocupada, em 7 de dezembro de 1937, inicia-se o controlo da Imprensa através da Presidência da Junta Técnica do Estado, encarregada da autorização legal para o exercício do jornalismo, da condenação dos elementos ligados ao governo republicano e o estabelecimento da censura ${ }^{15}$. Com a vitória das tropas de Franco, surge vinculada à Falange, a Vice-secretaria de Educação Popular, que entre 1941 e 1945, vai agir como um verdadeiro aparelho de propaganda do regime franquista. Dividida em duas delegações, a Delegação Nacional de Propaganda e a Delegação Nacional de Imprensa, a VSEP é encarregada da difusão do ideário falangista e da ação censória que o Estado, via partido, passa a exercer sobre a sociedade como um todo. Para tal, conta com representações provinciais e dispõe de meios apropriados como a obrigatoriedade do registo de jornalistas, o controlo da distribuição de papel para os jornais e demais publicações periódicas, a censura prévia de publicações, emissões radiofónicas, exibições teatrais ou quaisquer atos públicos. Em 1951 é criado, por fim, um Ministério de Informação e Turismo, consagrado a exercer oficialmente a função de defesa do ideário do Estado ${ }^{16}$.

Assim sendo, em nome de uma imagem irreal da "Nação", os Estados autoritários dos anos trinta, nomeadamente os de cunho fascista, exercem a repressão, legitimando-a através de um discurso em prol daqueles que consideram os seus verdadeiros "cidadãos”. O apelo à violência é levado a cabo como uma reação a um inimigo externo, "estrangeiro" e "anti-nacional". A visão de um mundo ordenado é mantida à custa da eliminação das vozes discordantes, o que, por vezes, pode implicar o extermínio. Os profissionais do jornalismo são, antes de mais nada, propagandistas dos regimes.

nazi é notória e recai de forma mais aguda sobre a produção alemã do período de Weimar. Lembrar a tentativa feita por Goebbels para denegrir a arte moderna, expressionista e abstrata, a chamada "arte degenerada", quando da exposição com o mesmo nome em 1937.

${ }^{15}$ Um relato sobre a questão da censura e da imprensa, no estilo de depoimento, é feito em Eduardo de Guzmán. Historias de la Prensa, Madrid. Penthalon ediciones, 1982. Ver ainda: J. Terron. La prensa en España durante el régimen de Franco. Un intento de análisis político. Madrid, C.I.S., 1981.

${ }^{16} \mathrm{O}$ seu diretor é um falangista, Gabriel Arias Salgado, autor de uma obra intitulada Política Espanhola de Informação, na qual considera como dever da Imprensa servir os interesses do Estado. Sobre o tema ver, entre outros, Bartolomé Bennassar. Histoire des Espagnols. XIII-XX siècle. Paris, Armand Colin, 1985, v.2. Sobre a repressão e o controlo da imprensa na época fraquista ver, entre outros, Manuel Fernández Areal. Consejo de Guerra. Los riesgos del Periodismo bajo Franco. Pontevedra, Diputación de Pontevedra, 1997. 
Em Portugal, com o advento da Ditadura Militar e a consolidação do Estado Novo, os mecanismos de delimitação da cidadania e de controlo da sociedade oferecem múltiplos parâmetros para uma possível comparação entre o caso português e os modelos clássicos fascistas.

\section{2. "Tudo pela Nação, nada contra a Nação": os limites da cidadania no Estado Novo.}

A liberdade garantida pelo Estado, condicionada pela autoridade, é a única possível, aquela que pode conduzir, não digo à felicidade do homem, mas à felicidade dos homens. . ${ }^{17}$

Para o Estado Novo português e para o salazarismo, considerado como a base ideológica do regime, a noção de cidadania está, de igual forma, vinvulada ao nacionalismo e à aceitação dos pressupostos ideológicos ditados pelo regime. Por consequência a cidadania pressupõe "passividade" e aceitação das normas impostas pelo poder, que se apresenta como um defensor da "Nação".

Neste contexto, o cidadão, parte integrante da "Nação", deve agir de forma a não quebrar o sentido da proposta organizadora do Estado. A cidadania é a definição de um conjunto de deveres que "qualificam" uma identidade "nacional”, o "ser português”. A noção de “cidadania plena” é restrita àqueles que fazem parte deste esquema ordenador, ou seja, das instituições diretamente vinculadas ao Estado, como a Legião Portuguesa ou a União Nacional, cabendo aos demais a adesão incondicional aos seus postulados ideológicos, já que "desejam" sentir-se nacionais, ou seja, ser "portugueses"18.

O lema do regime, "Tudo pela Nação, nada contra Nação”, possui, portanto, uma dupla leitura. Por um lado, é uma ordem de comando que parte do poder constituído para todo e qualquer elemento que se possa considerar “português". Por outro, é a imagem da coesão e da "resposta" conjunta da

\footnotetext{
${ }^{17}$ Declarações de Salazar a António Ferro. Salazar. O homem e a sua obra. Lisboa, Empresa Nacional de Publicidade, 1933, p. 51.

${ }^{18} \mathrm{O}$ direito de participação do cidadão na organização dos órgãos de soberania do Estado Novo existe, porém, de forma legal. De facto, o Presidente da República é eleito por sufrágio direto dos cidadãos, maiores de 21 anos, alfabetizados ou que possuam rendimentos elevados e pelas mulheres que tenham um curso especial do ensino secundário ou curso superior (Decreto-Lei n. ${ }^{\circ} 23406$ de 27 de dezembro de 1933). A partir das eleições de 1965, no entanto, de acordo com o disposto na Lei n. ${ }^{\circ} 2100$ de 29 de agosto de 1959, o sufrágio passa a ser realizado por um colégio eleitoral.
} 
sociedade em prol do regime, sendo Salazar considerado o arquétipo, o símbolo de Portugal.

Tal como ocorre em outros países, os direitos liberais da cidadania encontram-se legalmente garantidos pela legislação que rege o Estado Novo português ${ }^{19}$. Segundo a Constituição de 1933, Portugal é uma "república unitária e corporativa, baseada na igualdade dos cidadãos perante a lei" ${ }^{\prime \prime}$, na qual se advoga a liberdade de religião, de expressão do pensamento, de ensino, e se garante esta mesma liberdade àquele que, acusado de algum crime, não tenha "culpa formada"'s1, favorecendo ainda a liberdade de reunião e a resistência às ordens que "infrinjam as garantias individuais" do cidadão $0^{22}$. No entanto, a necessidade de coadunar estas noções com o perfil traçado pelo regime do seu "cidadão ideal" gera um contradiscurso no qual é afirmado o carácter coercivo e limitador do Estado. Assim sendo, é prevista uma legislação especial para o exercício da liberdade de expressão ou reunião $0^{23}$, sendo autorizada a prisão sem culpa formada dos acusados de crimes contra "a segurança do Estado" ${ }^{24}$.

No entanto, esta mesma legislação, que permite a liberdade de pensamento, prevê o controlo das suas formas de expressão, justificando a coerção como forma de "impedir preventiva ou repressivamente a perversão da opinião pública na sua função social e salvaguardar a integridade moral dos cidadãos" ${ }^{25}$. O Estado assume uma ação repressiva que é justificada pela necessidade de defender os seus "cidadãos" dos "factores que desorientem a sua visão contra a verdade, a justiça, a boa administração e o bem comum" ${ }^{\text {"26 }}$. O próprio Salazar, nas entrevistas a António Ferro, em 1932, publicadas no Diário de Notícias, de Lisboa, afirma que se a liberdade de pensamento é "sagrada" e a "censura é uma instituição injusta", é necessário, por todos os meios, reprimir a difusão de qualquer "doutrina subversiva"

Nos mais diversos discursos produzidos por ideológos ou membros do Estado Novo, é reafirmada esta imagem da cidadania. Em 1934, o Decálogo do

\footnotetext{
${ }^{19}$ Sobre o texto constitucional e as suas reformas ver, entre outros, Fernando Rosas. "As Grandes Linhas da Evolução Institucional”, in : Fernando Rosas. (coord.). Portugal e o Estado Novo (1930-1960). Nova História de Portugal.v. XII. Lisboa, Editorial Presença, 1992. ${ }^{20}$ Artigo $5^{\circ}$ da Constituição de 1933.

${ }^{21}$ Artigo $8^{\circ}$ da Constituição de 1933.

${ }^{22}$ Artigo $19^{\circ}$ da Constituição de 1933 .

${ }^{23}$ Parágrafo $2^{\circ}$ do Artigo $20^{\circ}$ da Constituição de 1933.

${ }^{24}$ Parágrafo $3^{\circ}$ do Artigo $20^{\circ}$ da Constituição de 1933.

${ }^{25}$ Artigo 20 parágrafo $2 .{ }^{\circ}$ da Constituição de 1933.

${ }^{26}$ Título VI, artigo 22 da Constituição de 1933.

${ }^{27}$ António Ferro. op. cit., p. 46 e ss.
} 
Estado Novo, define os valores da cidadania e da liberdade do cidadão, sempre subordinados aos parâmetros impostos pela necessidade de um Estado forte para Portugal e justifica a repressão. A liberdade individual, ideia mestra da noção de cidadania no liberalismo, é concebida como uma faculdade que só pode ser exercida no interior das "associações" reconhecidas como "naturais" pelo discurso oficial, como a família e as corporações. Tem, pois, menos o sentido de "liberdade" do que "liberdades", o que se compreende devido ao liberalismo característico do Estado Novo e ao corporativismo, que se radicava quer na consciência tradicionalista, quer no cristianismo social, quer na nova ideologia fascista:

As liberdades autênticas revivem na orgânica do Estado Novo, quer tomando o aspecto de liberdades políticas, pelo regresso à justa representação nacional, quer tomando o aspecto de liberdades municipais, pela criação, no maior grau possível, de autarquias administrativas, quer tomando o aspecto de liberdades profissionais, pelo regresso ao grémio e ao sindicato, agrupados na corporação, dentro da disciplina, da ordem e da unidade ${ }^{28}$.

Em 1935, Manuel Rodrigues, professor da Faculdade de Direito de Coimbra e então Ministro da Justiça, traça o perfil da boa cidadania num discurso, proferido em Viana do Castelo, intitulado "O cidadão do Estado Novo". Para ele, o "primeiro dever" de um cidadão é "desempenhar bem o lugar que lhe for confiado" ${ }^{29}$, ou seja, exercer a sua função produtiva de acordo com os padrões impostos pelo regime. Aos trabalhadores, cabe, portanto, o trabalho, e aos proprietários alcançar o máximo de rentabilidade na atividade produtiva que promovem. Colocado em segundo lugar, está o exercício político da cidadania, no qual o principal dever é o da defesa do Estado.

É o cidadão obrigado a defender o Estado visto ele ser a condição indispensável da existência social e salvaguarda da ordenação do País, e é ainda obrigado a defendê-lo na estrutura das ideias que professa. É obrigado a defender o Estado porque sem ele não há ordem, nem justa e duradoura relacionação de atividades, nem seria possível perpetuar a Nação ${ }^{30}$.

\footnotetext{
${ }^{28}$ Secretariado de Propaganda Nacional. Decálogo do Estado Novo, Lisboa, SPN, 1934, p. 42 (em itálico no original).

${ }^{29}$ Manuel Rodrigues. O cidadão do Estado Novo. Lisboa, União Nacional, 1935, p. 16.

${ }^{30}$ Manuel Rodrigues. op. cit., p. 27.
} 
A crítica à atuação estatal, se porventura existir, deve ser fruto de um estudo dos problemas existentes e das razões apresentadas pelo regime para as suas resoluções, mas, até aqui, deve prevalecer a ideia de que o Estado Novo, como promotor do nacionalismo, não age fora de preceitos morais próprios da "nação". Frente a isto, toda a ação do regime tem a sua razão de ser, cabendo ao cidadão a sua aceitação. O cidadão do Estado Novo é, portanto, "obrigado a pôr a sua atividade ao serviço do Estado"31.

Neste contexto, a imagem da ordem perfeita é transfigurada na visão de um Portugal de "aldeias brancas" e das "gentes de brandos costumes". O "bom cidadão" é apresentado como aquele que participa das manifestações a favor do regime, como as realizadas por ocasião das comemorações oficiais do $1{ }^{\circ}$ de Maio, com direito a foto nas primeiras páginas dos periódicos, mas também como o "bom português", configurado, por exemplo, como a boa gente da aldeia, como os camponeses que apareceram nas cenas do documentário Jornal Português $\mathrm{n}^{\circ}{ }^{\circ}$, de dezembro de 1938 , intitulado A Nossa Terra, A Aldeia mais Portuguesa de Portuga ${ }^{32}$, realizado por António Lopes Ribeiro, acerca das aldeias concorrentes ao concurso da "Aldeia mais portuguesa de Portugal", realizado pelo SPN. Nas mensagens mais “diretas" é de destacar, porém, a presença da juventude, em especial a imagem dos jovens, que são apresentados nos documentários cinematográficos oficiais dos desfiles da Mocidade Portuguesa, como aquele intitulado "Parada da Mocidade no $1 .{ }^{\circ}$ de Dezembro", filmado para as Comemorações do Duplo Centenário.

Em A Revolução de Maio, uma das tentativa de propaganda direta do regime no sector das longa-metragens, são delineados outros perfis da cidadania. $\mathrm{O}$ exemplo da cidadania "positiva" é apresentado pela heroína do filme, Clara, uma jovem enfermeira que se coloca ao lado do Estado Novo e aplaude as suas realizações ${ }^{33}$. Em sentido diferente, um outro exemplo de "bom cidadão" é dado pelo revolucionário que, perante a experiência das ações do regime em prol da "Nação", nomeadamente dos trabalhadores do campo e da

\footnotetext{
${ }^{31}$ Manuel Rodrigues. op. cit., p. 28.

${ }^{32}$ Monsanto, aldeia vencedora, aparece mencionada em outros documentários da série "Jornal Português", como no "Jornal Português", n. . 9, de junho de 1939, que dedica algumas imagens à entrega do "Galo de Prata" à aldeia, voltando a ser lembrada em dezembro de 1945 no "Jornal Português" , n. ${ }^{\circ}$ 53, que trata, entre outros temas, da sua festa anual.

${ }^{33}$ Numa das primeiras tomadas da película esta personagem é apresentada como parte de uma multidão que aplaude entusiasticamente mais uma das realizações do Estado Novo na área da construção naval.
} 
cidade, se converte aos ideais do Salazarismo, aceitando mesmo as penas que lhe deveriam ser imputadas. Por outro lado, temos personagens cuja conduta tipifica o mau exercício da cidadania ou a ausência completa da qualidade do "bom português". No primeiro caso, salienta-se a personagem de Barata "Boateiro" que, sem ser assumidamente de esquerda, como funcionário público possui uma atuação condenável ao fomentar a difusão de boatos contrários ao regime. No segundo, é acentuada a tónica ao "não-nacionalismo" dos elementos vinculados ao chamado "reviralho" através das personagens ligadas à tentativa de revolução : o russo, portanto, "não português", seria a "prova" da ligação da oposição do regime ao comunismo internacional34; e o dono da tipografia, que possui um comportamento social condenável.

Estas imagens, no entanto, são difundidas de outras e de múltiplas formas, sobretudo no auge da campanha anti-comunista dos anos trinta e dos anos quarenta ${ }^{35}$. Em 1945, por exemplo, circulam pelo país os Cadernos Anti-Comunistas, que definem, através da visão negativa, a conduta a ser tomada pelo bom cidadão. Estes Cadernos, compostos em Lisboa e de responsabilidade não assumida, propõem-se "prevenir o perigo que para a nossa integridade nacional" representa "o avanço do sovietismo russo para ocidente" ${ }^{36}$. Os artigos procuram sempre "dar um rosto" ao comunista, abordando-o em títulos como "Carta a um trabalhador português e comunista", de Sérgio Lima ${ }^{37}$, ou ainda, "Conversando com uma comunista", por Helena Dias Andrade ${ }^{38}$. O "comunista" é um indivíduo que se opõe aos valores morais do cidadão ideal do regime, como é o caso da mulher comunista. Dona de "uma expressão dura, a "comunista" é masculinizada", declarando ser os filhos "importunos", ansiando pela sua "emancipação", através da realização profissional39. Como todos os outros não-cidadãos, ela representa uma gama de persona-

\footnotetext{
${ }^{34}$ A personagem Dimoff é representada por Eliezer Kamenesky, antiquário e figura conhecida nos meios lisboetas. Ver: Félix Ribeiro. Filmes, Figuras e Factos da História do Cinema Português. 1896-1949. Lisboa, Cinemateca Portuguesa, 1983.

35 Sobre o tema ver: Telmo Daniel Faria. "O comunismo: um anátema estado-novista”, in: Revista de História das Ideias. Faculdade de Letras da Universidade de Coimbra. n ${ }^{\circ}$ 17.1995. 36 “Tudo pela Nação". Apresentação. in: Cadernos Anti-Comunistas. Ano Primeiro, Lisboa, 20 de janeiro de $1945,{ }^{\circ}{ }^{\circ} 1$.

${ }^{37}$ Cadernos Anti-Comunistas. 3 de fevereiro de 1945, n. $^{\circ} 3$.

${ }^{38}$ Cadernos Anti-Comunistas. 24 de fevereiro de 1945, n. ${ }^{\circ}$ 6. Este número é dedicado "À mulher portuguesa", sendo apresentado como o "grito de alarme contra a mais feroz das ameaças que jamais se levantou no mundo a pôr em perigo a dignidade e a honra de todas as mulheres".

${ }^{39}$ Helena Dias Andrade. “Conversando com uma comunista”, in: op. cit. s.p.
} 
gens estranhas à Nação, apresentadas como "seres repelentes, de paixões loucas e desmedidas, tratantes incapazes de pensar, máquinas, instintos em ação, prontos a cometer crimes por ordem do seu Senhor: Staline"40.

Esta tónica de crítica ao anti-nacionalismo, presente durante toda a vida do regime, é retomada com uma outra ênfase no anos cinquenta, quando ocorrem os primeiros conflitos anti-coloniais. Em 1954, a invasão dos enclaves indianos é vista como uma obra da ação comunista no mundo, e os noticiários dos principais jornais de Lisboa dão destaque para as manifestações "nacionalistas" de apoio ao salazarismo realizadas em diversos países pelas colónias lusas de emigrantes ${ }^{41}$.

\section{A construção da cidadania: as formas de controlo e de propaganda.}

A imprensa deve saber que há numerosas formas possíveis de atuação administrativa através das quais “inocentemente” se pode negar na prática, diminuir ou distorcer a sua liberdade legal... ${ }^{42}$

Para construir uma imagem do "bom cidadão" é necessário, antes de mais nada, promover o "saneamento" da sociedade através da eliminação e do controlo daqueles que tentam romper com os padrões estabelecidos. A instituição dos meios pelos quais será efetuado este processo é, no entanto, iniciada através de um ofício expedido pelo governo, logo após o advento da Ditadura Militar em 1926. Nesta nota, os jornais são avisados da implantação de uma "censura de facto", sem base legal, que obriga o envio de exemplares dos periódicos para os comandos da Guarda Nacional Republicana (GNR), onde deveriam ser cortadas as notícias consideradas "inconvenientes” para a nova ordem política ${ }^{43}$.

Em 1931, uma circular da Direção dos Serviços de Censura, datada de 28 de agosto, restabelece as coordenadas pelas quais deveriam ser pautadas as atuações dos censores no controlo dos periódicos. A neutralização da im-

${ }^{40}$ Maria Niolet de Moura. “O Cortejo...”, in: op.cit. s.p.

${ }^{41}$ O Diário de Notícias, de 3 de agosto de 1954, apresenta na sua primeira página a fotografia do movimento levado a cabo pela colónia portuguesa do Rio de Janeiro. Diário de Notícias, Lisboa, 3 de agosto de 1954, p.1.

${ }^{42}$ Salazar. "Caminho do Futuro" (Discurso proferido na sede da União Nacional de Lisboa, em 1 de julho de 1958), in : Discursos e Notas Políticas. 1951-1958. vol. V, Coimbra, Coimbra Editora, 1959, p.507.

43 Sobre o tema ver Graça Franco. A Censura à Imprensa (1820-1974). Lisboa, Universidade Católica Portuguesa-Imprensa Nacional, 1993. 
prensa como "arma política" usada contra o regime é expressa no decorrer de pontos diversos, como a proibição de veiculação de noticiário sobre os atentados de carácter político ou, simplesmente, a existência de críticas ao regime. A imprensa, visando a "reabilitação moral" da Nação, deve, de igual forma, deixar de lado as notícias que atentem contra a "dissolução de costumes", como notícias sobre "suicídios", "infanticídios", ou ainda, anúncios de "astrólogos, bruxas, videntes" ou de "empregos de moral suspeita"44.

Em 1933, o sistema de controlo e censura da sociedade é finalmente regularizado, com a criação das Comissões de Censura, pelo Decreto-Lei n.o 22 469, de 11 de abril de 1933, e do Secretariado de Propaganda Nacional (SPN), já que, para forjar a cidadania nos moldes do regime, não basta somente a repressão. Vinculadas ao SPN e, posteriormente, ao SNI, as Comissões de Censura organizam um relatório semanal sobre a imprensa portuguesa. O Boletim da Imprensa, como é designado, abrange os jornais de Lisboa, do Porto, dos pequenos núcleos das Províncias, das Ilhas, das Colónias do Ultramar e da Colónia Portuguesa do Brasil. Neste Boletim é comunicado aos demais órgãos da administração do governo a tendência política da Imprensa, atestando ou não a sua proximidade do ideário do Estado $\mathrm{Novo}^{45}$, ou acentuando a falta de "integração" nos pressupostos do regime ${ }^{46}$. Estes relatórios apresentam os cortes e os artigos de relevo para o regime publicados pelos mais diversos periódicos. Assim sendo, afirma-se, por exemplo em relação aos Açores, que do "ponto de vista político não existem jornais adversários do Estado Novo, e os neutros publicam, de quando em quando, notícias e até artigos favoráveis à atual governação portuguesa"47.

É preciso, no entanto, preencher os vazios deixados nos jornais e "reeducar" os cidadãos. Neste sentido, o Estado Novo, como dissemos, lança mão da propaganda com a criação do Secretariado de Propaganda Nacional ${ }^{48}$,

\footnotetext{
${ }^{44}$ Circular de 28 de agosto de 1931, citada por Graça Franco. A Censura à Imprensa (18201974). Lisboa, Universidade Católica Portuguesa-Imprensa Nacional, 1993, p. 98.

${ }^{45}$ Alguns destes relatórios foram localizados na documentação relativa aos anos 30 e 40 do Ministério do Interior, que se encontra na Torre do Tombo em Lisboa.

46 "Continua a ser impossível afirmar que os jornais se sintam integrados e correspondam com eficácia aos deveres de verdadeiros órgãos orientadores da opinião pública, que deviam ser" (Relatório Mensal da Imprensa Diária de Lisboa e Porto. Fevereiro de 1943. Item: “Aspectos Gerais”. Ministério do Interior. Gabinete do Ministro. A.N.T.T. Maço 530.) ${ }^{47}$ SPN. Boletim da Imprensa. Outubro de 1936. p.1. Ministério do Interior. Maço 467. A.N.T.T. ${ }^{48} \mathrm{O}$ Secretariado de Propaganda Nacional é criado pelo Decreto Lei n. ${ }^{\circ} 23$ 054, de 25 de setembro de 1933. Sobre o tema ver: Heloísa Paulo. Estado Novo e Propaganda : o SPN/SNI e o D.I.P. Coimbra, Minerva Editora, 1994.
} 
posteriormente designado Secretariado Nacional de Informação, Cultura Popular e Turismo (SNI)49. O objetivo de ambos é "integrar os portugueses no pensamento moral que deve dirigir a Nação" ${ }^{\circ}$, sendo um misto de aparelhos repressores e órgãos de propaganda. Na verdade, a repressão e a propaganda não deixam de caminhar juntas em toda a trajetória do regime, já que ambas possuem um objetivo comum: o de manter a ordem e os padrões da cidadania vigente. Mas, na verdade, o SPN, detém diversas "frentes" de propaganda direta", para além da escrita e da imagem, possuindo atribuições especiais que vão desde a intermediação entre a imprensa e o Estado à organização de manifestações nacionais ou outros atos que sirvam para "combater por todos os meios ao seu alcance a penetração no nosso País de quaisquer ideias perturbadoras e dissolventes da unidade e do interesse nacional" ${ }^{1}$.

Para o exercício do controlo dos meios de comunicação, nomeadamente a imprensa, o SPN, em dezembro de 1939, cria um boletim semanal policopiado $^{52}$ que "fornece à Imprensa pequenas notícias, indicações, sugestões, dados estatísticos, notas bibliográficas, elementos de trabalho", os quais, no entanto, devem ser "tanto quanto possível, comentados, desenvolvidos, adaptados ao meio, por forma a evitar ou pelo menos contrariar nos jornais que recebem Informações a tendência para a uniformidade"ş.

O substituto do SPN, o SNI, novo somente na sua denominação e na maior amplidão da sua ação repressiva, é, por outro lado, mais centralizador da ação de controlo da informação no país, reunindo, entre as suas atribuições, as funções de repressão dispersas por numerosos organismos e decretos-lei. O SNI passa a ter as seguintes funções: o registo e licença dos jornalistas e das agências noticiosas, a censura prévia, o controlo da radiodifusão ${ }^{54}$, podendo manter fiscais permanentes junto às emissoras para "visto prévio" de todos os textos a difundir ${ }^{55}$, e ainda a execução das antigas atribuições da Inspeção

49 O Secretariado Nacional de Informação, Cultura Popular e Turismo é instituído a 23 de fevereiro de 1944, pelo decreto-lei n. ${ }^{\circ} 33545$.

${ }^{50}$ Preâmbulo do decreto-lei n. ${ }^{\circ} 23$ 054, de 25 de setembro de 1933. p. 5.

${ }^{51}$ Artigo 4, alínea f, do decreto-lei n. ${ }^{\circ} 23054$.

${ }^{52}$ Em fevereiro de 1943 o número de Informações registava para o mês de janeiro cerca de 217 artigos distribuídos, 197 deles publicados em periódicos e 114 transcrições, por número, do mesmo boletim. Ver Informações. Fevereiro de 1943. p. 6.

${ }^{53}$ Boletim Informações, n. ${ }^{\circ}$ 119, de 9 de março de 1942.

${ }^{54} \mathrm{Ao}$ assumir a tarefa explicitada pelo artigo 4 do decreto-lei n. ${ }^{\circ} 29937$, de 21 de setembro de 1939, conforme o disposto no Item 2, "Da Informação", artigo 3 do decreto-lei n. ${ }^{\circ} 34134$ de 24 de novembro de 1944.

${ }^{55}$ Artigo 16 do decreto-lei n. ${ }^{\circ} 34$ 134, de 24 de Novembro de 1944. 
dos Espectáculos ${ }^{56}$. Com esta última atribuição, o órgão passa a centralizar a fiscalização e o fornecimento de registo, licenças e vistos para toda e qualquer manifestação artística ou casa de espectáculo aberta ao público, exercendo deste modo forte vigilância sobre a vida cultural e artística do país. Com o mesmo fim controlador é criado o Conselho de Imprensa, formado pelo diretor do Secretariado, o diretor dos Serviços de Censura, o Chefe da Repartição de Informação e os diretores dos jornais diários. Reúne-se uma vez por mês e procura "assegurar o contacto entre os jornais e o Estado, elucidando-os acerca do pensamento governativo e ouvindo as sugestões que entenderem formular no interesse da sua missão" ${ }^{77}$.

O Estado Novo, no decorrer das décadas seguintes, aprimora a sua ação censora no sentido de "defender" os seus ideais de cidadania. Com o advento da televisão, em 1957, a ordem de serviço n. ${ }^{\circ}$, aprovada pelo Conselho de Administração da Rádio e Televisão Portuguesa regulamenta a fiscalização dos programas $5^{5}$. Os primeiros noticiários televisivos seguem a linha de conduta estabelecida para os demais meios de comunicação, apresentando a visão oficial do regime acerca das suas decisões políticas. À programação televisiva é interdita, de igual forma, a divulgação de programas que possam ser "perniciosos à educação do povo". Em 1964, com a criação do Gabinete de Exame e Classificação de Programas, o "novo" meio de comunicação é definitivamente subordinado aos parâmetros oficiais de controlo e censura.

\section{Cidadania e Informação: os meios de comunicação ao serviço da propaganda do Estado.}

...o jornal é o alimento espiritual do povo e deve ser fiscalizado como todos os alimentos ${ }^{59}$.

...tenho ligado a propaganda à educação política do povo português e lhe tenho atribuído duas funções - informação primeiro; formação política depois.

\footnotetext{
${ }^{56}$ Regulamentado pelo Artigo 5 do decreto-lei n. ${ }^{\circ} 34133$, de 24 de novembro de 1944.

${ }^{57}$ Artigo 7 do decreto-lei n. ${ }^{\circ} 34$ 133, de 24 de novembro de 1944.

${ }^{58}$ Esta norma tinha por base o decreto-lei n. ${ }^{\circ} 41$ 051, de 1 de abril de 1957. Ver : Francisco Rui Cádima. Salazar, Caetano e a Televisão Portuguesa, Lisboa, Editorial Presença, 1996, p. 46 e ss.

${ }^{59}$ Declaração de Salazar a António Ferro in :Salazar o homem e a sua obra. Lisboa, Empresa Nacional de Publicidade, 1993, p. 48.
} 
Em ocasiões diversas devo ter proferido duas frases, que uma à outra se completam e traduzem o que acerca do primeiro ponto poderia dizer: 'Politicamente só existe o que se sabe que existe'; 'politicamente o que parece é ${ }^{60}$.

Os jornalistas, responsáveis pela "opinião pública”, defendida pela Constituição de 1933 como "elemento fundamental da política e administração do País" cidadão". Um ponto de referência é dado pelo próprio diretor do SPN/SNI, António Ferro, escritor, modernista, jornalista de profissão e o primeiro a divulgar em entrevistas a figura de Salazar.

Todos os jornalistas, portanto, e, em especial, os donos dos periódicos, devem ser considerados "pessoas de reconhecida idoneidade intelectual e moral" ${ }^{2}$.É obrigatório o porte de um registo para o exercício da profissão, e, como os demais "cidadãos" do regime, os profissionais do jornalismo estão "representados" nos respectivos organismos corporativos, como o Grémio Nacional da Imprensa Diária e o Sindicato Nacional dos Jornalistas. Aos jornalistas estrangeiros ou ligados às agências noticiosas internacionais, as exigências são detalhadas, sendo o seu registo emitido pelo órgão de propaganda e renovado periodicamente.

O primeiro exemplo é dado por aqueles que trabalham nos meios de comunicação diretamente subordinados ao Estado, como a Emissora Nacional. Os jornalistas destes organismos são obrigados a assinar uma declaração, do tipo da que era assinada por qualquer funcionário público, onde afirmavam a sua integração na "ordem social e política estabelecida pela Constituição de 1933" e o seu "ativo repúdio do comunismo e de todas as ideias subversivas" ${ }^{\text {"3. }}$. Para o melhor jornalista, a propaganda oficial oferece o Prémio "Afonso de Bragança", cujo nome homenageia um "grande jornalista português nacionalista" ${ }^{4}$, um jovem repórter, falecido em 1922, sidonista e diretor do matutino A Situação.

Como exemplos do jornalista-cidadão do regime podemos citar alguns nomes, dos quais o mais renomado fora, sem dúvida, o do próprio diretor do

\footnotetext{
${ }^{60}$ Salazar. "Fins e Necessidade da Propaganda Política". (Discurso proferido na reunião das Comissões da União Nacional de Lisboa, em 26 de fevereiro de 1940), in : Discursos e Notas Políticas.1938-1943. vol. III, Coimbra, Coimbra Editora, s.d., p. 195-196.

${ }^{61}$ Título VI, artigo 22, da Constituição de 1933.

${ }^{62}$ Decreto-lei n. ${ }^{\circ} 26589$, de 14 de maio de 1936.

${ }^{6}$ Artigo 1. $^{\circ}$ do decreto-lei n. ${ }^{\circ} 27003$, de 13 de maio de 1937.

${ }^{64}$ António Ferro. Prémios Literários, SNI, Lisboa, 19, p. 32.
} 
SPN-SNI, António Ferro. Como cronista, repórter e crítico, Ferro trabalha em diversos jornais portugueses no período anterior ao Estado Novo, nomeadamente nos jornais $O$ Século, O Jornal, órgão do Partido Republicano Conservador, O Imparcial, Diário de Lisboa , para além de dirigir a revista Ilustração Portuguesa. Na sua trajetória como repórter são célebres as entrevistas com os mais importantes nomes da política do entre-guerras, como Mussolini, Primo de Rivera, Mustapha Kemal, Pétain, Clemenceau. Em 1932, torna-se célebre ao entrevistar Salazar, publicando, em 1933, o mais famoso livro de entrevistas ao político português, Salazar - o Homem e a Sua Obra, que foi traduzido para várias línguas. Na sequência deste encontro, é chamado para dirigir o órgão de propaganda do regime, onde permanece até 1949.

Para além de Ferro temos, porém, uma série de outros nomes que alcançam relevo pela defesa que promovem do regime na sua função de jornalistas. Como exemplo, podemos citar Luís Teixeira, jornalista, redator do Diário de Notícias, membro da Câmara Corporativa entre 1938 e 1942, sendo também o autor do livro Perfil de Salazar, premiado pelo SPN, em 1938, com o Prémio Ramalho Ortigão, destinado ao melhor ensaio ${ }^{65}$. As suas reportagens, no entanto, em duas ocasiões, 1939 e 1945, recebem do SPN o prémio Afonso de Bragança. Assim como a publicação acerca do Presidente do Conselho, as matérias vencedoras tratavam de apresentar uma forte argumentação a favor do regime, abordando assuntos relacionados com a política externa do governo de Salazar. A primeira delas, "Epopeia dos Humildes”, uma reportagem publicada no Diário de Notícias, fruto da sua visão, como correspondente, versa sobre os acontecimentos da Guerra Civil de Espanha. A segunda apresenta uma série de crónicas com argumentações que "atestam" a colaboração "não assumida" por Portugal com os aliados, nomeadamente ingleses e americanos, no decorrer da Segunda Grande Guerra. O conjunto destes textos é publicado com o título de "Neutralidade Colaborante", neste mesmo ano ${ }^{66}$.

Um outro nome do jornalismo que se destaca pela a sua atuação em prol do regime é Leopoldo Nunes. Como jornalista, trabalha em diversos periódicos como A Época, A Voz, o Diário da Tarde e o Diário de Notícias, estabelecendose, a partir de 1931 em O Século. Em 1935, assume o cargo de redator da Assembleia Nacional. Como escritor possui a primeira obra que versa sobre Salazar,

\footnotetext{
${ }^{65}$ Esta obra é traduzida, em 1940, para espanhol e francês, e em 1943 para o inglês, tornando-se, ao que parece, a obra do género mais divulgada neste período.

${ }^{66}$ Ver Luís Teixeira. Neutralidade Colaborante, Lisboa, Editorial Ática, 1945.
} 
datada de 1930, intitulada O Ditador das Finanças ${ }^{67}$. Durante a Guerra Civil espanhola, segue para a Espanha franquista como correspondente de guerra do citado jornal, publicando as suas experiências como correspondente de guerra em trabalhos eminentemente propagandísticos do franquismo e do Estado Novo português, como A Guerra de Espanha ou Madrid Trágica ${ }^{68}$. São alguns nomes que destacamos, entre os quais poderíamos ainda acrescentar o de Augusto de Castro, que se tornou um dos jornalistas mais interessantes do Estado Novo.

Para que o jornalista-cidadão não tivesse dúvidas quanto à sua atuação, o Boletim Informações fornecia indicações acerca do perfil do bom exercício da cidadania. Em 29 de abril de 1941, por exemplo, Informações "recomenda" a reprodução da notícia acerca da manifestação de estudantes ocorrida em Coimbra por ocasião das manifestações do dia 28 desse mês, data comemorativa da entrada de Salazar para o governo, como um exemplo do "sentimento de orgulho e de fé nacional"69. Um ano antes, o mesmo boletim afirmava a adesão do país às comemorações do Duplo Centenário e a sua gratidão às realizações do regime ${ }^{70}$. No decorrer da guerra, é dado destaque à atitude "nobre" da sociedade portuguesa que, solidária com a "hora grave" então vivida, não realiza no Carnaval os cortejos e as "mascaradas ridículas"71. Sempre citada, a Mocidade Portuguesa, exemplo para a juventude do país, merece diversas menções, entre elas a da iniciativa de incentivar o "reaportuguesamento" das tradições de Natal em Portugal, com o retorno ao presépio tradicional ${ }^{72}$.

Durante diversos momentos políticos, podemos constatar o controlo acirrado da censura e a substituição da informação pela propaganda aberta. É o que ocorre, por exemplo, durante a Guerra Civil em Espanha, ou ainda, no decorrer da guerra colonial. No primeiro caso, como já vimos, inúmeros correspondentes de periódicos portugueses deslocam-se ao cenário do conflito,

\footnotetext{
${ }^{67}$ Sobre a temática das biografias de Salazar ver : Heloisa Paulo. "Salazar: a elaboração de uma imagem”. Revista de História das Ideias. Faculdade de Letras da Universidade de Coimbra. n¹8.1996.

${ }^{68}$ Sobre o tema ver Alberto Pena Rodrigues. El Estado de Oliveira Salazary la Guerra Civil española: información, prensa y propaganda (1936-1939). Tesis Doctoral apresentada no Departamento de Historia de la Comunicación Social de la Facultad de Ciencias de la Información de la Universidad Complutense de Madrid, 1997.

${ }^{69}$ SPN. Informações , 29 de abril de 1941, p. 4.

$7^{\circ}$ SPN. Informações, 14 de outubro de 1940, p. 2 e 3.

${ }^{71}$ SPN. Informações, 19 de janeiro de 1942, p. 4.

${ }^{72}$ SPN. Informações , 29 de dezembro de 1941, p. 4.
} 
oferecendo uma visão que contribui para a imagem oficial que o regime fornece do acontecimento : o choque entre o internacionalismo e as forças comunistas, figuradas pelos republicanos, e os defensores do nacionalismo e da fé, chefiados pelos generais Franco e Mola ${ }^{73}$. A censura promove cortes nos noticiários que falam das atrocidades cometidas pelos revoltosos, mas, paralelamente, incentiva a divulgação de dados que denigram a imagem dos “comunistas", ou seja, dos republicanos. Uma circular da Direção Geral de Censura, datada de 5 de agosto de 1936, declara que "tendo o movimento do exército espanhol uma feição caracterizadamente nacionalista e de luta contra o comunismo, deve ser permitido todo o noticiário que relate os excessos de toda a ordem que têm sido cometidos pelas milicias comunistas"74.

De facto, tudo que possa macular a imagem oficial do "bom cidadão", já descrita, é passível da ação censória. Nos jornais, da notícia do assassinato de uma mulher e do seu filho foram cortadas as menções ao assassino, marido e pai das vítimas, já que reveladoras da existência de "baixos sentimentos" na sociedade portuguesa ${ }^{75}$. Qualquer demonstração do "baixo nível cultural do nosso povo" ${ }^{6}$, ou de outra "característica" que não se coadune com o perfil de cidadania exposto, é motivo para a atuação dos órgãos repressores. No caso da televisão, por exemplo, os noticiários, acompanhados por comentários laudatórios ao regime, omitem relatos que possam "quebrar" com a imagem de bem-estar vigente, como em janeiro de 1965 quando da matéria sobre os efeitos provocados pelo tufão Claude em Lourenço Marques são cortadas as menções aos sem-abrigo e às cheias que sucedem ao fenómeno ${ }^{77}$.

$\mathrm{Na}$ verdade, uma parte da imprensa da época, ainda que controlada pelos censores e pela auto-censura, fruto do medo, conseguiu resistir a imagem da "boa cidadania" e da sociedade ideal apregoada pelo regime. Para cada tentativa de oferecer ao público uma outra leitura da realidade, a repressão atuava. Mas, ainda assim, a ação de jornais de grande dimensão, como o República, de Lisboa, ou de periódicos de província, como Jornal do Fundão, são exemplos "clássicos" da resistência aos "donos das vozes" do

\footnotetext{
73 Sobre o tema ver : Alberto Pena Rodrigues. op cit.

${ }^{74}$ Circular n. ${ }^{0} 126$ de 5 de agosto de 1936 citada por Alberto Pena Rodrigues, op. cit., p. 157.

75 Relatório da Censura. 11 de fevereiro de 1944. p. 3. Ministério do Interior. Maço 530. A.N.T.T.

${ }^{76}$ Alegação do censor para o corte efetuado da notícia apresentada a censura pelo periódico O Século a respeito do "tratamento selvático" de um animal por um camponês. Relatório da Censura. 20 de julho de 1944. p. 5. Ministério do Interior. Maço 530. A.N.T.T. ${ }_{77}$ Ver Francisco Rui Cádima. op. cit, p. 172.
} 
Media e espaço público

Estado Novo. Trabalhos parcelares sobre estes e outros jornais são fundamentais para se entender as estratégias usadas para tornear a censura e para apresentar um discurso diferente. Por isso a história do jornalismo precisa ser incrementada em perspectivas de análise sistemática, quer de natureza global, quer de tipo temático. 